University of Nebraska - Lincoln

DigitalCommons@University of Nebraska - Lincoln

USDA National Wildlife Research Center - Staff

Publications
U.S. Department of Agriculture: Animal and Plant Health Inspection Service

2011

\title{
Clinical and Pathologic Responses of American Crows (Corvus brachyrhynchos) and Fish Crows (C ossifragus) to Experimental West Nile Virus Infection
}

\author{
N. M. Nemeth \\ Colorado State University, nmnemeth@uga.edu \\ B. V. Thomsen \\ National Veterinary Services Laboratories \\ T. R. Spraker \\ Colorado State University \\ J. M. Benson \\ Colorado State University \\ A. M. Bosco-Lauth \\ Colorado State University \\ See next page for additional authors \\ Follow this and additional works at: https://digitalcommons.unl.edu/icwdm_usdanwrc \\ Part of the Environmental Sciences Commons
}

Nemeth, N. M.; Thomsen, B. V.; Spraker, T. R.; Benson, J. M.; Bosco-Lauth, A. M.; Oesterle, P. T.; Bright, J. M.; Muth, J. P.; Campbell, T. W.; Gidlewski, T. L.; and Bowen, R. A., "Clinical and Pathologic Responses of American Crows (Corvus brachyrhynchos) and Fish Crows (C ossifragus) to Experimental West Nile Virus Infection" (2011). USDA National Wildlife Research Center - Staff Publications. 1054.

https://digitalcommons.unl.edu/icwdm_usdanwrc/1054

This Article is brought to you for free and open access by the U.S. Department of Agriculture: Animal and Plant Health Inspection Service at DigitalCommons@University of Nebraska - Lincoln. It has been accepted for inclusion in USDA National Wildlife Research Center - Staff Publications by an authorized administrator of DigitalCommons@University of Nebraska - Lincoln. 


\section{Authors}

N. M. Nemeth, B. V. Thomsen, T. R. Spraker, J. M. Benson, A. M. Bosco-Lauth, P. T. Oesterle, J. M. Bright, J.

P. Muth, T. W. Campbell, T. L. Gidlewski, and R. A. Bowen 


\title{
Clinical and Pathologic Responses of American Crows (Corvus brachyrhynchos) and Fish Crows ( $C$ ossifragus) to Experimental West Nile Virus Infection
}

Veterinary Pathology 48(6) $1061-1074$

(C) The American College of

Veterinary Pathologists 20I

Reprints and permission: sagepub.com/journalsPermissions.nav DOI: $10.1177 / 0300985811398249$ http://vet.sagepub.com

(3)

\author{
N. M. Nemeth', B. V. Thomsen ${ }^{2}$, T. R. Spraker ${ }^{3}$, J. M. Benson ${ }^{3}$, \\ A. M. Bosco-Lauth ${ }^{3}$, P. T. Oesterle ${ }^{4,5}$, J. M. Bright ${ }^{6}$, J. P. Muth ${ }^{2,3}$, \\ T. W. Campbell ${ }^{6}$, T. L. Gidlewski ${ }^{5}$, and R. A. Bowen'
}

\begin{abstract}
West Nile virus (WNV)-associated disease has a range of clinical manifestations among avian taxa, the reasons for which are not known. Species susceptibility varies within the avian family Corvidae, with estimated mortality rates ranging from 50 to $100 \%$. We examined and compared virologic, immunologic, pathologic, and clinical responses in 2 corvid species, the American crow (Corvus brachyrhynchos) and the fish crow (C ossifragus), following experimental WNV inoculation. Unlike fish crows, which remained clinically normal throughout the study, American crows succumbed to WNV infection subsequent to dehydration, electrolyte and $\mathrm{pH}$ imbalances, and delayed or depressed humoral immune responses concurrent with marked, widespread virus replication. Viral titers were approximately 3,000 times greater in blood and 30,000 to 50,000 times greater in other tissues (eg, pancreas and small intestine) in American crows versus fish crows. Histologic lesion patterns and antigen deposition supported the differing clinical outcomes, with greater severity and distribution of lesions and WNV antigen in American crows. Both crow species had multiorgan necrosis and inflammation, although lesions were more frequent, severe, and widespread in American crows, in which the most commonly affected tissues were small intestine, spleen, and liver. American crows also had inflammation of vessels and nerves in multiple tissues, including heart, kidney, and the gastrointestinal tract. WNV antigen was most commonly observed within monocytes, macrophages, and other cells of the reticuloendothelial system of affected tissues. Collectively, the data support that WNV-infected American crows experience uncontrolled systemic infection leading to multiorgan failure and rapid death.
\end{abstract}

\section{Keywords}

bird, crow, experimental inoculation, pathology, West Nile virus

The number of birds that have died from West Nile virus (WNV) infection in North America is likely in the scale of millions. Numerous species within the family Corvidae, including crows, are highly susceptible to morbidity and mortality following WNV infection. ${ }^{7,17}$ The unusually high rates of WNV-associated mortality among corvids have led to speciesand population-level concerns, ${ }^{7,9}$ as well as incorporation of corvid carcass testing into public health surveillance strategies. ${ }^{11}$ Serologic surveys of free-ranging crows have revealed that seroprevalence among fish crows (Corvus ossifragus) is higher than that for American crows ( $C$ brachyrhynchos; approximately $15-50 \%$ vs $5-10 \%$, respectively). ${ }^{24,30}$ The scarcity of WNV-seropositive American crows suggests that few members of this species survive infection. ${ }^{30}$

The underlying reasons for differences in susceptibility to WNV infection among avian taxa are unknown, as are the
' Department of Biomedical Sciences, Colorado State University, Fort Collins, Colorado

${ }^{2}$ Pathobiology Laboratory, National Veterinary Services Laboratories, Ames, lowa

${ }^{3}$ Department of Microbiology, Immunology, and Pathology, Colorado State University, Fort Collins, Colorado

${ }^{4}$ Department of Fish, Wildlife, and Conservation Biology, Colorado State University, Fort Collins, Colorado

${ }^{5}$ National Wildlife Research Center, US Department of Agriculture, Animal and Plant Health Inspection Service, Wildlife Services, Fort Collins, Colorado

${ }^{6}$ Department of Clinical Sciences, Colorado State University, Fort Collins, Colorado

Corresponding Author:

N. M. Nemeth, Department of Pathology, University of Georgia, 50I DW Brooks Drive, Athens, GA 30602

Email:nmnemeth@uga.edu 
mechanisms behind WNV-induced death. Because survivors of WNV infection have a marked humoral immune response concurrent with successful virus clearance soon after infection, ${ }^{17,21}$ host immune responses may in part dictate ensuing patterns of virus replication and dissemination. However, some birds reach WNV titers of up to $10^{10}$ plaque-forming units (PFU) per milliliter of serum and rapid systemic dissemination of virus within days of infection..$^{10,21-23}$ Humoral immunity is initiated but dampened in these birds, followed shortly thereafter by illness and death. ${ }^{20,22}$ Specific physiologic responses and associated clinical manifestations following WNV infection in birds, such as the highly susceptible American crow, have not been examined.

The present study sought to characterize specific clinical responses and parameters and to correlate these with virus behavior and clinical outcomes of WNV infection in 2 corvid species: the American crow and the fish crow. Following experimental inoculation, we made successive assessments of hematology, blood chemistry, electrocardiology, and neurologic responses while documenting virus replication in serum, humoral antibody status, behavioral changes, and clinical progression. Gross and histopathologic examination was subsequently performed, infectious WNV quantified, and antigen deposition semiquantitatively assessed. These data were analyzed in concert to draw conclusions about the differing effects of WNV infection between 2 crow species.

\section{Materials and Methods}

\section{Crow Capture and Husbandry}

Eight crows (3 American crows and 5 fish crows) were captured by rocket net in June 2008 near Bartlesville, Oklahoma, and transported by air-conditioned truck to Fort Collins, Colorado. They were group housed in flight cages (initially outdoors and later indoors) for approximately 6 months before the study, after which they were transferred to a biosafety level 3 facility and individually caged $(30 \times 36 \times 18$ in $[76 \times 92 \times 46 \mathrm{~cm}])$. Rooms had natural lighting and were maintained at approximately 18 to $20^{\circ} \mathrm{C}$, and multiple perches and bark strips were provided to each cage. Wax paper was placed beneath each cage and changed daily. Water and food were provided ad libitum, and diet consisted of dog and cat food supplemented with apples and nuts. Birds were acclimated to cages for 4 days before inoculation.

\section{Inoculation and Sampling}

Birds were screened for antibodies to WNV and St Louis encephalitis virus just before inoculation, and only seronegative crows were used for inoculation. For each of 3 days immediately before inoculation, cloacal temperature, body weight, neurologic exam, fecal/urate observation, collection and analysis, and clinical assessments were made for each bird to establish relative normal responses and clinical parameters. Blood $(0.2 \mathrm{ml})$ was collected via the jugular vein once on each of these 3 days to establish baseline blood chemistry and hematologic parameters for each bird. A baseline electrocardiogram (ECG) was obtained for each bird before inoculation.

Three American crows and 3 fish crows were subcutaneously inoculated over the pectoral muscle with $0.1 \mathrm{ml}$ of approximately $10^{3.2} \mathrm{PFU}$ of WNV strain NY99-4132 (isolated in New York from American crow brain) in bovine albumin-1 (Hank's M-199 salts, 1\% bovine serum albumin, sodium bicarbonate $[350 \mathrm{mg} / \mathrm{liter}]$, penicillin [100 units $/ \mathrm{ml}]$, streptomycin [100 mg/liter], amphotericin B [1 mg/liter] in 0.05M Tris, $\mathrm{pH}$ 7.6). Two randomly selected fish crows served as noninfected controls for gross and histopathologic observations.

Following inoculation, birds were sampled every 24 hours for 6 days. Sampling and assessments occurred in the following order: noninvasive behavioral and clinical observations, cloacal temperature (mercury thermometer to $0.1^{\circ} \mathrm{C}$ ), blood collection via jugular or ulnar venipuncture (approximately $0.3 \mathrm{ml}$ ), ECG $(1,3,5$, and 6 days postinoculation [DPI]), neurologic examination, and body weight (electronic scale to $0.1 \mathrm{~g}$ ).

\section{Video Observations}

Sixty-minute video observations were conducted from outside the crow room through a one-way glass window, which began approximately 1 hour after dawn. Observations were made daily by the same person for 3 days before inoculation and 6 days following inoculation. Video observations served to document relative activity levels and frequency of common activities and behaviors, such as eating, drinking, preening, beak wiping, and full-body feather fluffing.

The percentage of time that each bird was active was calculated for each 60-minute daily video. Active status consisted of walking, hopping, manipulating available items (eg, apple, bark strips, leg band) or actively looking around, vocalizing, and preening. In some cases, activity involved active movement of head or wings while the body remained stationary. Birds were considered inactive when immobile for $\geq 15$ seconds.

\section{Clinical Assessment}

Body weight, body condition score (muscle mass over keel bone, graded 1-5), cloacal temperature, hydration status, capillary refill time over the ulnar wing vein $(<1,1-2,2-3$ seconds $)$, and general attitude were noted for each of 3 days before inoculation and every 24 hours after. Birds were euthanized if they exhibited signs of illness, such as decreased activity (eg, preening, eating, drinking).

\section{Fecal and Urate Analyses}

Daily observations on fresh droppings from each bird included color, cloudiness, consistency, and approximate urate:fecal ratio. The liquid (urate) portion of fresh droppings was collected with a sterile syringe directly from wax paper under cages and filtered onto a glass slide via filter paper (Whatman Qualitative, grade 1, $15.0 \mathrm{~cm}$; Biometra, Göttingen, Germany). 
Urate sediment on slides was air-dried and stained with Wright stain for viewing by light microscope. Urine-specific gravity was measured on the nonfiltered liquid portion of crow droppings via refractometer.

\section{Neurologic Examination}

Daily neurologic examinations included initial observations through one-way glass before entry (ie, birds unaware of human presence) and after entry while birds were in cages (ie, without direct manipulation). Mental status, posture, movement in cage, and response to human presence were included in these observations. In addition, an interactive neurologic examination was performed, which included assessments of proprioception (knuckling), postural reactions (placing exam and wing retraction), myotactic reflexes (noxious stimuli to digits of foot), pudendal nerve function (cloacal stimulus), cranial nerve function (eg, pupillary size and response to light, corneal reflex, beak strength, symmetry of oropharynx, gag reflex) and presence of neurologic signs, such as head tilt, nystagmus, circling, and ataxia.

\section{Electrocardiogram}

ECG readings were recorded on each crow 1 day before inoculation and at 1, 3, 5, and 6 DPI. All ECG recordings were made with a recording speed of $50 \mathrm{~mm}$ per second and a sensitivity of $1 \mathrm{mV} / \mathrm{cm}$. The underlying rhythm was noted and intermittent rhythm abnormalities, if present, described. Measured parameters included heart rate (beats per minute [bpm]), rhythm, $\mathrm{P}$ duration (seconds), $\mathrm{P}$ amp (millivolt) in lead avF, PR interval (seconds), QRS duration (seconds), S amp (millivolt) in lead avF, QT interval (seconds), and mean frontal plane electrical axis. The ST segment was evaluated for depression, elevation, and slurring.

\section{Blood Chemistry}

Immediately following collection via jugular or ulnar venipuncture, blood was placed into an i-STAT portable clinical analyzer with CG8 + cartridge as directed by the manufacturer (Heska Corporation, East Windsor, New Jersey). The following parameters were recorded: $\mathrm{pH}, \mathrm{PCO}_{2}, \mathrm{PO}_{2}$, base excess, $\mathrm{HCO}_{3}$, $\mathrm{TCO}_{2}, \mathrm{sO}_{2}$, sodium, ionized calcium, glucose, hematocrit, and hemoglobin.

\section{Hematology}

For blood cell estimations, blood smears were dried and then stained with Wright stain. The proportion each of the following was estimated per 100 leukocytes: lymphocytes, heterophils, eosinophils, basophils, and monocytes. Relevant morphologic abnormalities were noted, including polychromasia, hypochromasia, nuclear division (karyokinesis and cytokinesis), and abnormal cell shape (eg, elongation, compaction, and folding).

For hemacytometer readings, approximately $100 \mu \mathrm{l}$ of blood was placed into Microtainer tubes with lithium heparin
(200-400 $\mu$ l; Becton Dickinson, Franklin Lakes, New Jersey). Heparinized blood was diluted with Natt and Herrick stain solution, and leukocytes and erythrocytes were counted by light microscope $(40 \times$ objective) with a hemacytometer. Blood smears were prepared immediately following venipuncture and were fixed and stained with PROTOCOL Hema 3 Manual Staining System (ThermoFisher Scientific, Waltham, Massachusetts) according to manufacturer's instructions. One hundred cells were evaluated with a light microscope $(600 \times$ magnification) to obtain a differential count (lymphocytes, monocytes, heterophils, eosinophils, and immature erythrocytes). The percentage of immature erythrocytes was then added to the total erythrocyte count and subtracted from total leukocyte counts to determine the corrected total cell count (to account for similar staining of immature erythrocytes and leukocytes with Natt and Herrick solution).

\section{Virus Isolation}

Blood $(0.05 \mathrm{ml})$ was placed into cryovials with $0.45 \mathrm{ml}$ of bovine albumin-1 for an approximate 1:10 serum dilution, allowed to clot at room temperature for approximately 30 minutes, centrifuged for separation of serum $(12,000 \times g$ for 3 minutes), and stored at $-80^{\circ} \mathrm{C}$ until testing. Viral titers of sera and tissue homogenates were determined by PFU formed on Vero cell monolayers as previously described, ${ }^{5}$ with a minimum threshold for WNV detection of $10^{1.7} \mathrm{PFU} / \mathrm{ml}$ of serum and $10^{0.7} \mathrm{PFU} / \mathrm{ml}$ of tissue homogenate.

\section{Serologic Testing}

For serology, blood was collected directly into Microtainer serum separator tubes (Benton Dickinson), allowed to clot at room temperature for 30 to 60 minutes, centrifuged for separation of serum $\left(12,000 \times g\right.$ for 3 minutes), and stored at $-20^{\circ} \mathrm{C}$ until testing. Before testing, sera were heat inactivated $\left(56^{\circ} \mathrm{C}\right.$ for 30 minutes). Neutralizing antibody status was determined by plaque reduction neutralization test on Vero cell monolayers in 6-well plates as previously described. ${ }^{3}$ Sera collected before WNV inoculation were screened for antibodies at a 1:10 serum dilution to St Louis encephalitis virus with TBH-28 strain and to WNV with the same strain as for inoculation. Following inoculation, virus percentage neutralization was calculated on 4 to 6 DPI for sera diluted 1:20 in bovine albumin-1. For all plaque reduction neutralization test assays, the viral challenge dose was approximately $100 \mathrm{PFU}$.

\section{Pathology}

Two clinically healthy fish crows served as non-WNVinoculated controls for gross and histopathology. All crows were euthanized via intravenous sodium pentobarbital overdose and necropsied within 1 hour of death.

Tissues fixed in $10 \%$ neutral buffered formalin for histopathologic evaluation included brain, skeletal (pectoral) muscle, liver, lung, heart, kidney, proventriculus, ventriculus, 
small intestine, pancreas, large intestine, cervical spinal cord, bone marrow, and, in some cases, cloaca. Eyes were fixed in Davidson's fixative (3 parts 95\% ethanol, 2 parts 10\% formalin, 1 part glacial acetic acid, and 3 parts distilled water) for approximately 4 days and then placed in $70 \%$ ethanol. Vertebrae (from the thoracic spinal column) and/or metatarsal bone was decalcified in $10 \%$ formic acid with Amberlite IR-12OH beads (Aldrich, St Louis, Missouri) for approximately 7 days following initial formalin fixation. Tissues were embedded in paraffin, sectioned at $5 \mu \mathrm{m}$, and stained with hematoxylin and eosin.

Tissues collected for virus isolation included skeletal (pectoral) muscle, heart, liver, lung, spleen, pancreas, kidney, small intestine, gonad, brain, spinal cord, skin, eye, and feather. These tissues were homogenized and centrifuged as an approximate $10 \%$ tissue suspension as previously described. ${ }^{22}$

\section{Immunohistochemistry}

Immunohistochemistry was performed on formalin-fixed paraffin sections with an automated stainer (Ventana Medical Systems, Tucson, Arizona). Slides were placed in antigen retrieval solution and heated to $125^{\circ} \mathrm{C}$ for 10 minutes in a pressurized chamber (Diva Decloaker solution and Decloaking Chamber, Biocare Medical, Concord, California). After cooling and rinsing with buffer solution, nonspecific staining was blocked with 2 sequential blockers (Dual Endogenous Enzyme Block, Dako, Carpinteria, California; Discovery Antibody Block, Ventana Medical Systems). Anti-WNV monoclonal antibody (Clone 7H2, BioReliance, Rockville, Maryland) diluted 1:2500 was applied and incubated for 32 minutes, followed by secondary antibody and alkaline phosphatase detection (UltraView Universal Alkaline Phosphatase Red Detection Kit, Ventana Medical Systems). Slides were counterstained with hematoxylin. Tissues known to be WNV positive and negative were included as controls in each staining trial.

Immunohistochemical staining for WNV antigen was semiquantitatively scored for each tissue per the following scale: $0=$ no WNV antigen, $1=$ low numbers of cells containing WNV antigen in focal or multifocal areas, $2=$ moderate numbers of cells containing WNV antigen in multifocal areas, and 3 $=$ large numbers of cells with WNV antigen throughout the section.

\section{Statistical Analysis}

The MIXED procedure (SAS Institute, Cary, North Carolina) with repeated measures was used for data analysis, and Akaike information criteria (AIC) was used for model selection ${ }^{6}$ to test which sets of factors best predicted select dependent variables (ie, percentage activity, behaviors, viremia profiles, and select biochemistry parameters) based on 5 models each. Species and DPI were considered fixed effects, and individual AIC weights were calculated for each model. Model 1 (intercept only) represented a scenario in which the dependent variable was independent of all fixed parameters included within the model set.
Models 2 and 3 tested single effects of either species or DPI on each dependent variable; model 4 was additive (species + DPI) and model 5 interactive (species $\times$ DPI). In addition, peak viremia was analyzed as a function of species by analysis of variance (ANOVA) GLM procedure (SAS Institute), with viremia as the dependent variable and species as the fixed variable.

\section{Results \\ Video Observations}

Activity levels in all birds decreased by 6 DPI, but the decrease was earlier in onset and more pronounced in American versus fish crows. American crows were active approximately 30 to $60 \%$ of the time before inoculation and through 4 DPI, approximately 10 to $20 \%$ on 5 DPI, and $0 \%$ on 6 DPI. In general, fish crows were more active than American crows, with 2 of 3 fish crows being active 90 to $100 \%$ of time through 6 DPI; activity in the third fish crow was high through 4 DPI but decreased at 5 and 6 DPI (to approximately $70 \%$ and $22 \%$, respectively). Predominant active behaviors for both species consisted of beak wiping and preening.

All models for percentage activity and individual behaviors indicated that specific measured activities (except drinking) were affected by WNV infection and that the effects differed by species and DPI (additive and/or interactive models). The frequency of drinking showed no apparent difference associated with species or DPI (see Supplemental Table 1 found at http://vet.sagepub.com/supplemental).

\section{General Clinical and Neurologic Signs}

Fish crows maintained their body weights throughout the experiment, whereas American crows decreased between 2 and $13 \%$ of preinoculation body weights by 6 DPI. The weight of 1 American crow (No. 1) decreased 51 g (approximately 10\%) between preinoculation and 5 DPI but subsequently increased $26 \mathrm{~g}$ between 5 and 6 DPI. Hydration levels in 1 American crow (No. 1) and 1 fish crow (No. 5) decreased following infection, as evidenced by increased capillary refill time and decreased skin turgor. Cloacal temperatures in fish crows were between 43.0 and $44.0^{\circ} \mathrm{C}$ before and following infection, except for No. 5, which reached $45.0^{\circ} \mathrm{C}$ on 5 DPI but returned to $44.0^{\circ} \mathrm{C}$ on $6 \mathrm{DPI}$. American crows had cloacal temperatures of 43.0 to $44.0^{\circ} \mathrm{C}$ before and early after inoculation, whereas all 3 birds reached 44.5 to $45.2^{\circ} \mathrm{C}$ between 3 and 5 DPI. On 6 DPI, 2 American crows (Nos. 2 and 3) were hypothermic with temperatures of 39.5 and $42.2^{\circ} \mathrm{C}$, whereas the third bird (No. 1) died before assessment of cloacal temperature at 6 DPI.

Among the 3 fish crows, mental attitude, posture, balance, proprioception, and reflexes appeared normal throughout the study except at 6 DPI, when myotactic reflexes were diminished in all 3 birds and pupillary response was delayed in 1 (No. 4). Among the 3 American crows, myotactic reflexes appeared diminished as early as 2 DPI, whereas other neurologic assessments were normal until 5 DPI, at which time all 3 birds were less alert and made only weak attempts to move 
Table I. Virus Quantification in Select Tissues and Frequency of Gross and Histopathologic Lesions in Fish and American Crows Experimentally Inoculated With West Nile Virus

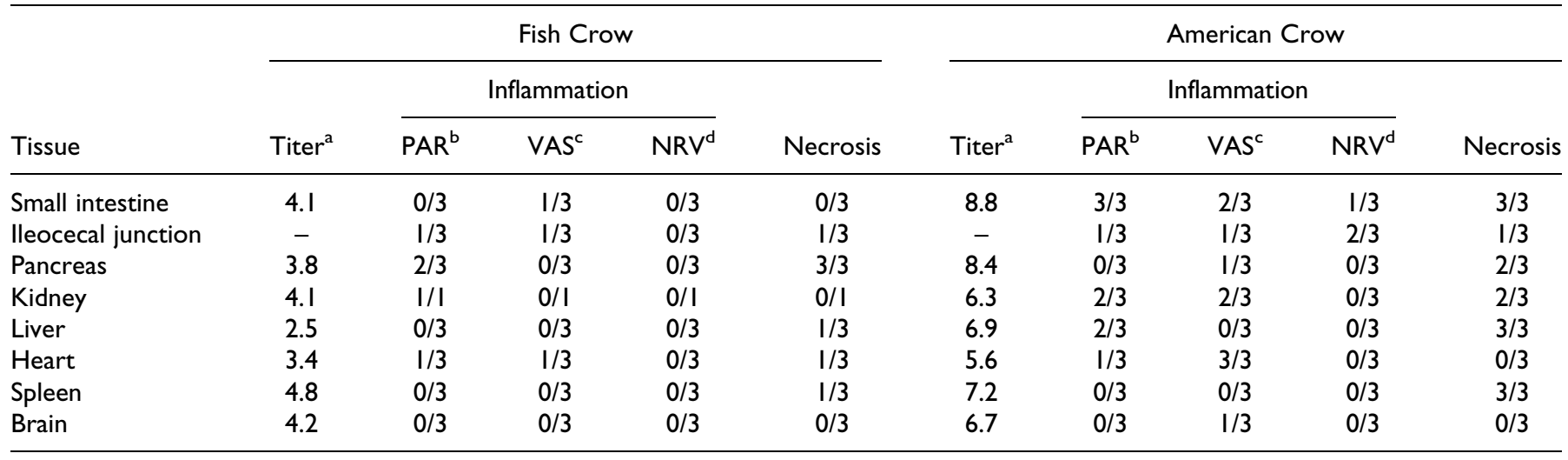

${ }^{a}$ Mean titer among individuals of the respective species in log plaque-forming units per milliliter of $10 \%$ tissue homogenate. Birds euthanized 6 days postinoculation (for complete data, see Supplemental Table 3).

b Parenchyma.

c Vasculature-included perivascular cuffing (sometimes with vasculitis).

${ }^{d}$ Nerves-included neuritis (sometimes with ganglionitis).

away. One of these also had decreased pupillary responses and mild ataxia (No. 1). At 6 DPI, all American crows were noticeably lethargic; 2 were recumbent with severe ataxia (Nos. 1 and 3 ); and the third remained perched with intermittent episodes of labored breathing and ataxia (No. 2). Myotactic reflexes were delayed or absent in all American crows, and all had abnormal pupillary responses, which ranged from delayed to hyperresponsive (the latter included pinpoint pupils). Proprioception and postural reactions were delayed in the 2 recumbent American crows, and both had weakened beak strength. Responses observed during the interactive neurologic examination were difficult to interpret because of the potentially overriding effects of handling and restraint-induced stress and because of the apparent stoic attitude of the crows throughout the study.

One American crow died during examination at 6 DPI (No. 1 ), whereas the other 2 were lethargic and poorly responsive and thus euthanized immediately after examination. Three fish crows remained alert and had no overt clinical signs at 6 DPI, at which time they were also euthanized.

\section{Fecal and Urate Analyses}

Before WNV inoculation, most crows had an approximate urate:fecal ratio of 1:1 with uniformly cloudy white urates and formed brown feces. At 1 DPI, fish crows had a decreased urate:fecal ratio but with normal coloration of white and brown (urates and feces). By 1 DPI, American crows had an increased urate:fecal ratio, with profuse watery diarrhea that continued over time; in addition, urates were discolored (green or yellow) at 5 DPI. Urine-specific gravity increased in all crows following inoculation, with preinoculation and early postinoculation levels of approximately 1.010 to 1.020 . At 6 DPI, urinespecific gravity of fish crows was between 1.028 and 1.035 , and fecal and urate output had decreased in 2 of these birds. American crow fecal and urate output at this same time point was nearly zero, and only 1 bird's urine-specific gravity could be measured, owing to lack of liquid; it was $>1.045$. No abnormalities in numbers or morphologies of crystals or casts were observed upon microscopic examination of urate sediment.

\section{Electrocardiogram}

All crows remained in normal sinus rhythm throughout the study period. In addition, ECG intervals, duration, amplitudes, and mean electrical axis values remained relatively constant. Before inoculation, heart rates ranged from 250 to 333 beats per minute (bpm) among American crows and 300 to $400 \mathrm{bpm}$ among fish crows. From 1 to 5 DPI, heart rates of American crows remained at or below preinoculation levels (within 50 to $100 \mathrm{bpm}$ ), whereas at $6 \mathrm{DPI}$, rates had elevated from 17 to $127 \mathrm{bpm}$ above preinoculation rates. Heart rates in fish crows were increased for only a single time point per bird $(3,5$, or 6 DPI) with a 50- to 125 -bpm increase versus those measured before inoculation.

\section{Blood Chemistry}

Glucose, hemoglobin, and hematocrit levels decreased following WNV inoculation in all crows. Two of 3 American crows (Nos. 1 and 2) had uncompensated metabolic acidemia at 6 DPI $\left(\mathrm{pH}<7.35\right.$, normal $\mathrm{PaCO}_{2}$ and low $\mathrm{HCO}_{3}$ ), whereas the third (No. 3) had uncompensated respiratory alkalemia $(\mathrm{pH}=7.5$, low $\mathrm{PaCO}_{2}$ and normal $\mathrm{HCO}_{3}$ ). Also at $6 \mathrm{DPI}$, American crows were hyponatremic, hyperkalemic, and hypocalcemic. Blood chemistry measurements over time (including preinoculation and postinoculation) suggested that sodium, potassium, glucose, hematocrit, and hemoglobin levels were affected by WNV infection. For statistical analyses, the best AIC models included interactions between species and time, suggesting that species and DPI have an additive and synergistic effect on the change in the aforementioned blood chemistry values (see Supplemental Table 2). 
Table 2. Immunohistochemical Scoring (0-3) of Tissues From American and Fish Crows Following Experimental West Nile Virus Infection ${ }^{\mathrm{a}}$

\begin{tabular}{lcccccccccc}
\hline Species & Heart & Lung & Liver & Spleen & Kidney & Pancreas & Proventriculus & Small Intestine & Brain & Spinal Cord \\
\hline American & I-2 & 2 & 3 & 3 & 2 & $2-3$ & $2-3$ & 3 & 1 & 2 \\
Fish & I & I & I & I-2 & I & $0-1$ & I & 1 & $0-1$ & 0 \\
\hline
\end{tabular}

${ }^{\mathrm{a}}$ For complete data, see Supplemental Table 4.

\section{Hematology}

Before inoculation, crows had no evidence of anemia or abnormal cell morphologies. In addition, relative eosinophil and monocyte numbers were higher than what was observed after experimental inoculation. All crows had a mild to moderate leukocytosis from 0 to $2-3 \mathrm{DPI}$, as followed by heterophilia and lymphocytosis (Figs. 1-3). Occasional reactive lymphocytes were observed in 2 of 3 American crows and 2 of 3 fish crows between 4 and 6 DPI. Erythrocyte numbers decreased over time in all crows.

\section{Virus and Antibody Quantification}

Peak viremia titers were significantly higher in American crows $\left(10^{8.2-9.6} \mathrm{PFU} / \mathrm{ml}\right.$ serum $)$ than in fish crows $\left(10^{4.7-6.3}\right.$ $\mathrm{PFU} / \mathrm{ml}$ serum; analysis of variance, $P=.005$ ). Peak titers occurred between 3 and 4 DPI in fish crows and between 4 and 5 DPI in American crows. By 6 DPI, viremia titers in fish crows had declined to $10^{1.7-2.2} \mathrm{PFU} / \mathrm{ml}$ serum, whereas titers in American crows remained high until all were severely moribund at 6 DPI $\left(10^{7.3-7.7} \mathrm{PFU} / \mathrm{ml}\right.$ serum; Fig. 4). The best AIC model was interactive, indicating that both species and DPI had an impact on viremia profiles (see Supplemental Table 2).

All crows had infectious WNV in at least 12 of 14 tissues at 6 DPI, with peak titers in fish crows in eye and lung $\left(10^{5.7}\right.$ and $10^{5.2} \mathrm{PFU} / \mathrm{ml}$ homogenate, respectively), in contrast to American crows, in which titers were highest in small intestine and pancreas $\left(10^{8.8}\right.$ and $10^{8.4} \mathrm{PFU} / \mathrm{ml}$ homogenate, respectively; Table 1). Virus was isolated at low titers from mature feathers $\left(10^{2.7} \mathrm{PFU} / \mathrm{ml}\right.$ homogenate $)$ of 1 fish crow and 1 American crow.

All crows had $<50 \%$ serum neutralization of WNV and St Louis encephalitis virus before inoculation and were therefore considered negative for past infection. On 4 DPI, no crows had evidence of seroconversion. However, at 5 DPI, all fish crows had evidence of anti-WNV antibodies, with 87 to $91 \%$ neutralization at a 1:20 serum dilution, which increased to 93 to $100 \%$ by 6 DPI. American crows had weaker humoral antibody responses than fish crows did, between 41 and $64 \%$ neutralization at 5 DPI and between 69 and $79 \%$ at 6 DPI (Fig. 5).

\section{Pathology}

Upon necropsy, all American crows had pasty vent and poor body condition and were dehydrated, whereas fish crows were in good body condition with normal hydration status. Gross lesions included diffusely pale livers in all 6 inoculated crows,

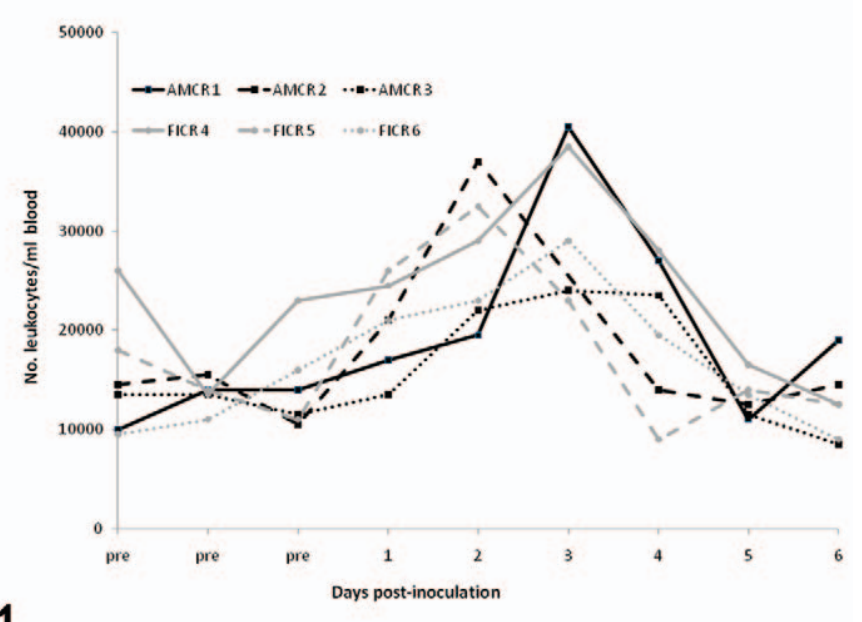

1

Figure I. Leukocytes prior to and following experimental inoculation of American and fish crows with West Nile virus.

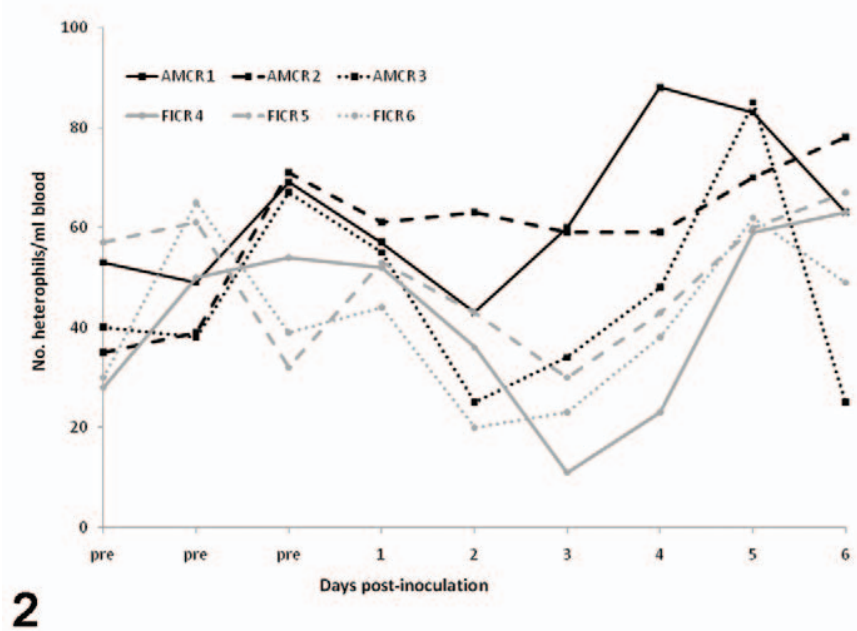

Figure 2. Heterophils prior to and following experimental inoculation of American and fish crows with West Nile virus.

and most had splenomegaly ( 3 to 4 times normal size). All American crows had mild to moderate opacity of air sacs; No. 3 also had approximately $0.5 \mathrm{ml}$ of serosanguinous fluid in the coelomic cavity, whereas No. 2 had 2 to $3 \mathrm{ml}$ of clear yellow fluid in the coelomic cavity. All American crows had mild cerebral congestion. Two American crows (Nos. 2 and 3) had 


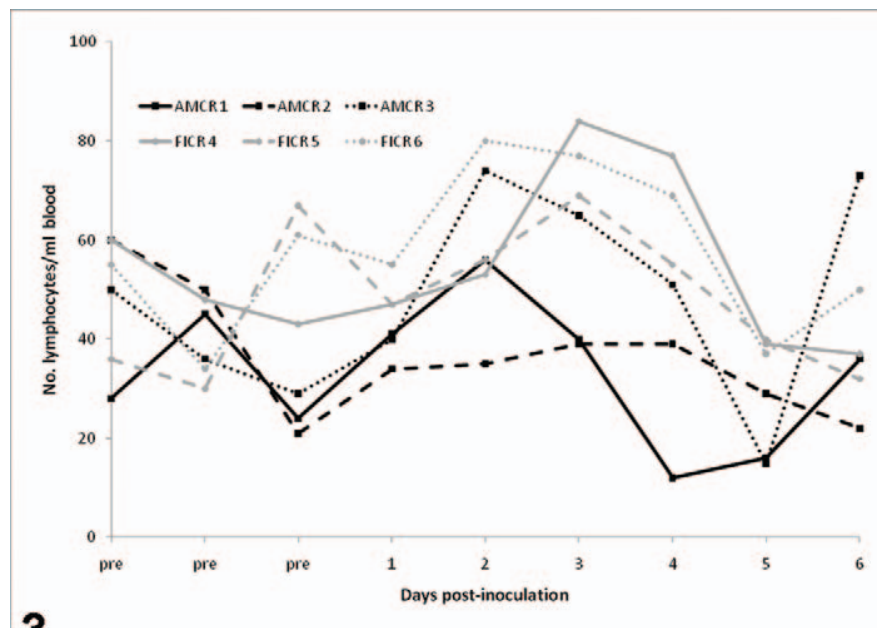

3

Figure 3. Lymphocytes prior to and following experimental inoculation of American and fish crows with West Nile virus.

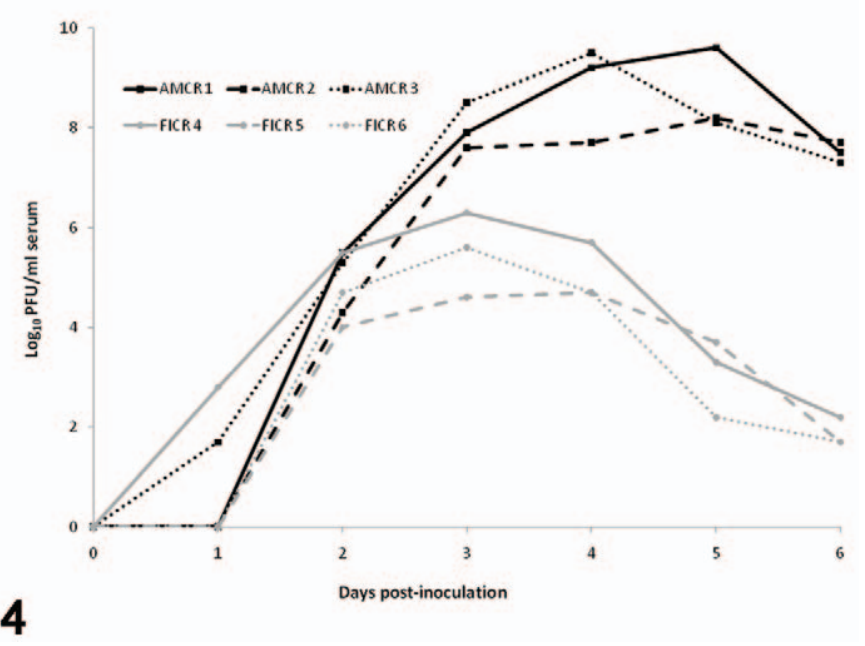

Figure 4. Viremia profiles in American and fish crows following experimental inoculation with West Nile virus.

uniformly dilated intestines, one of which (No. 3) contained reddish viscous fluid. The pancreas of this crow had multiple red round-to-ovoid foci (1- to 4-mm diameter) on the surface; the other pancreas (No. 2) was enlarged. The same 2 American crows had diffuse dark discoloration of the kidneys, with one also having renomegaly.

Two noninoculated control fish crows were confirmed WNV negative by reverse transcription polymerase chain reaction of pooled tissues (brain, kidney, spleen, heart). As with gross observations in inoculated crows, one negative control crow had splenomegaly and mild centrilobular fatty degeneration of the liver.

Histologic changes were observed within numerous tissues of WNV-inoculated American crows. In all 3 American crows, the majority of hepatocytes contained multiple intracytoplasmic vacuoles that were well defined, circular, and variably sized (compatible with lipid) with mild multifocal hepatocellular swelling (degeneration). All 3 American crows also had mild renal tubular necrosis; 2 (Nos. 1 and 3) also had mild lymphoplasmacytic inflammation in the interstitium, including perivascular and vascular inflammation and endothelial cell swelling. All 3 American crows had moderate to severe splenic lymphoid depletion with increased plasma cells within the red pulp, and Nos. 1 and 3 had moderate to severe lymphoid necrosis.

All 3 American crows had mild myocardial degeneration consisting of variable degrees of myocytolysis, nuclear swelling, and pyknosis, with loss of striations and myofiber vacuolization. There was concurrent fibrosis, sometimes with thrombi. All had lymphoplasmacytic myocarditis, with perivascular cuffing, vasculitis, and epicarditis (Fig. 6). In addition, 1 American crow (No. 1) had mild ganglionitis within the pericardial adipose tissue. All 3 American crows had mild, acute to chronic rhabdomyolysis, with mild to absent inflammation.

Two American crows (Nos. 1 and 2) had mild lymphocytic ganglioneuritis in the myenteric plexus of the proventriculus and/or ventriculus, with occasional necrotic neurons and variable perivascular cuffing and vasculitis (Fig. 7). Two American crows (Nos. 2 and 3) also had perivascular inflammation and ganglionitis near the cloaca and ureter (Figs. 8, 9). Two of 3 American crows (Nos. 1 and 3) had moderate multifocal necrosis of the pancreas (Fig. 10), whereas the other (No. 2) had mild perivascular inflammation in the pancreas. All 3 had mild to moderate cryptitis characterized by lymphoplasmacytic inflammation (Fig. 11) and low numbers of heterophils within dilated intestinal crypts, as well as necrosis of the duodenal muscular layer. No. 2 had a mild granulomatous coelomitis. No. 1 had ganglionitis and vasculitis in the duodenum with segmental multifocal lymphoplasmacytic neuritis in the distal small intestine and large intestine, which also had perivascular hemorrhages.

There were no significant lesions in eye, spinal cord, or brain of any crow except for 1 American crow (No. 2), with a single focus of mild lymphoplasmacytic perivascular cuffing and swollen astrocytes in the cerebrum. In general, bone marrow samples were inadequate for assessment, but necrosis was observed in the bone marrow of 1 American crow (No. 3).

Similar to American crows but much less severe, all 3 inoculated fish crows had diffuse intracytoplasmic hepatocellular vacuolation and degeneration, sometimes with mild lymphoplasmacytic inflammation. Both negative control fish crows had none to mild hepatic vacuolar degeneration. Cardiac lesions were minimal in fish crows; they included mild multifocal perivascular inflammation, focal necrosis, and nuclear swelling. In addition, 1 fish crow (No. 5) had mild ganglionitis within the pericardial adipose tissue. The spleen of 1 fish crow (No. 6) had lymphoid hyperplasia with increased plasma cells in the red pulp and follicular cell necrosis. One fish crow (No. 5) had mild infiltration of plasma cells and macrophages in the lamina propria of the ureter with some heterophils migrating through the transitional epithelium. All 3 fish crows 


\begin{tabular}{|c|c|c|c|c|c|}
\hline \multirow[b]{2}{*}{$\begin{array}{l}\text { West Nile virus } \\
\text { infection }\end{array}$} & \multicolumn{5}{|c|}{ Days post-inoculation } \\
\hline & $1-2$ & 3 & 4 & 5 & 6 \\
\hline \multirow[t]{3}{*}{ AMERICAN CROW } & $\begin{array}{l}\text { Initiation of WNV } \\
\text { replication in blood }\end{array}$ & \multicolumn{3}{|c|}{ Leukocytosis and lymphocytosis } & $\begin{array}{c}\text { High systemic viral } \\
\text { titers } \\
\text { Epithelial cell damage }\end{array}$ \\
\hline & & \multirow[t]{2}{*}{ Rising viremiatiters } & \multicolumn{2}{|c|}{$\begin{array}{c}\text { Peakviremiatiters } \\
\text { Hyperthermia }\end{array}$} & $\begin{array}{c}\text { Intestinal } \\
\text { malabsorption }\end{array}$ \\
\hline & & & & $\begin{array}{l}\text { kantibody } \\
\text { sponse }\end{array}$ & $\begin{array}{l}\text { Acictbase and } \\
\text { electrolyte imbalances }\end{array}$ \\
\hline
\end{tabular}

\begin{tabular}{ccc} 
Initiation of WNV & $\begin{array}{c}\text { Reduced activity and alertness } \\
\text { Diarrhea and dehydration } \\
\text { Death }\end{array}$ \\
\hline replication in blood & Leukocytosis and lymphocytosis & $\begin{array}{c}\text { Robust humoral } \\
\text { immune response }\end{array}$ \\
Initial humoral \\
immune response
\end{tabular}

Figure 5. Proposed progression of West Nile virus infection in the American and fish crow. Time points are estimated based on data from the present study.

had mild focal acute pancreatic necrosis; 2 (Nos. 4 and 6) also had mild inflammation. One fish crow (No. 6) had mild focal vasculitis in the duodenum; another (No. 5) had mild multifocal perivascular inflammation in the large intestine and ceca, with severe heterophilic inflammation in cecal lamina propria and mucosal necrosis (Table 1). Two of 3 inoculated fish crows (Nos. 4 and 5) and 1 of 2 negative control fish crows had mild rhabdomyolysis, ranging from acute to chronic, with mild to no inflammation (see Supplemental Table 3).

Concurrent nonviral infections were observed in 1 American crow (No. 3) with numerous bacterial colonies in lung, heart, kidney, spleen, and proventriculus and in 1 fish crow (No. 4) with fungal hyphae in the crypts of the small intestine. Incidental findings in American crows included multiple sarcocysts in the myocardium (No. 1), microfilaria in the duodenum (No. 1), and Tetrameres sp in the proventriculus (No. 3).

\section{Immunohistochemistry}

WNV antigen was detected by immunohistochemistry in multiple cell types within multiple tissues, with abundant antigen present in American crows and lesser amounts in fish crows (Table 2). Among tissues examined, WNV antigen was most commonly observed within monocytes, macrophages, and other cells of the reticuloendothelial system. In livers of American crows, there was abundant WNV antigen in Kupffer cells, monocytes, and macrophages, with lesser amounts in endothelial cells, perivascular connective tissue, and biliary epithelium (Fig. 12). WNV antigen was rarely detected in livers of fish crows, and its distribution was limited to Kupffer cells and monocytes (Fig. 13). In kidneys of American crows, primarily intact cells but also degenerate and necrotic renal tubular epithelial cells within the cortex and medulla were the major locations of WNV antigen, with lesser amounts in monocytes, glomeruli, endothelium, and tubular interstitium (Fig. 14). In the single fish crow kidney examined (No. 5), WNV antigen distribution was limited to rare intravascular monocytes (Fig. 15). Within spleens of American crows, there was abundant antigen in mononuclear phagocytic cells in red and white pulp, along with the infrequent staining of the endothelium (Fig. 16). Spleens of the fish crows also had WNV antigen in mononuclear phagocytic cells of the red and white pulp, but there were markedly fewer cells with WNV antigen (Fig. 17).

In the gastrointestinal tract of American crows, the mucosal epithelium was the primary site of WNV antigen. The proventricular glandular epithelium contained abundant antigen, with lesser amounts in macrophages within the lamina propria, monocytes, endothelial cells, and, infrequently, smooth muscle cells. Sections of ventriculus had antigen in similar cell types as the proventriculus, but amounts were greatly reduced. In duodenum and ileum, there was abundant antigen in the crypt and villous epithelium, with lesser amounts in monocytes, macrophages, and endothelial cells (Fig. 18). Antigen-containing cells in the crypts were most commonly intact but occasionally degenerate or necrotic and sloughed from the basement membrane. Small amounts of antigen were also present in intestinal 


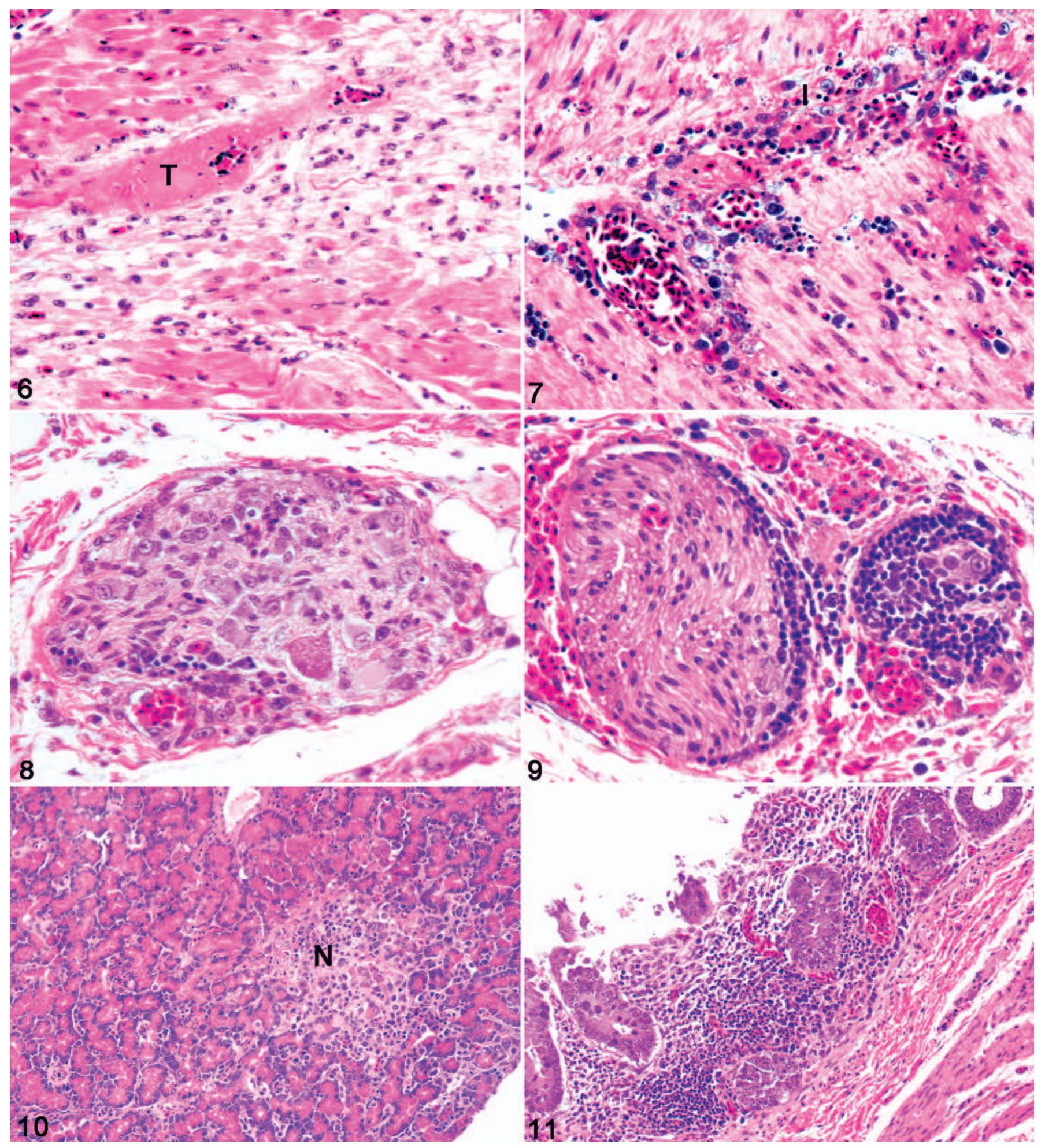

Figure 6. Heart; American crow No. I. A focal area of myocardial necrosis characterized by myocardial cell degeneration, myocardial fiber loss, thrombosis of a small to medium sized artery $(T)$, and early interstitial fibroplasia. This lesion suggests myocardial infarction. HE. Figure 7. Myenteric plexus; American crow No. 2. Inflammation within a myenteric plexus of the midjejunum. The vasculitis is a prominent feature and is characterized by necrosis of the vascular wall, with cuffing by lymphocytes and plasma cells. Inflammation is also present within the myenteric plexi, as characterized by an infiltration of lymphocytes and plasma cells (I). HE. Figure 8. Ganglion; American crow No. I. A parasympathetic ganglion adjacent to the cloaca is heavily infiltrated with lymphocytes and a few plasma cells. Note the eosinophilic, necrotic neuron. HE. Figure 9. Ganglion and nerve; American crow No. 2. A parasympathetic ganglion and nerve adjacent to a ureter are heavily infiltrated with lymphocytes and plasma cells; the nerve is cuffed, with a low number of lymphocytes and plasma cells. HE. Figure I0. Pancreas; American crow No. I. A focal area of necrosis characterized by pyknotic nuclear debris (N) and infiltration of lymphocytes and plasma cells. HE. Figure I I. Small intestine; American crow No. I. Marked lymphoplasmacytic infiltrate surrounding the villi and obliterating crypts. HE. 


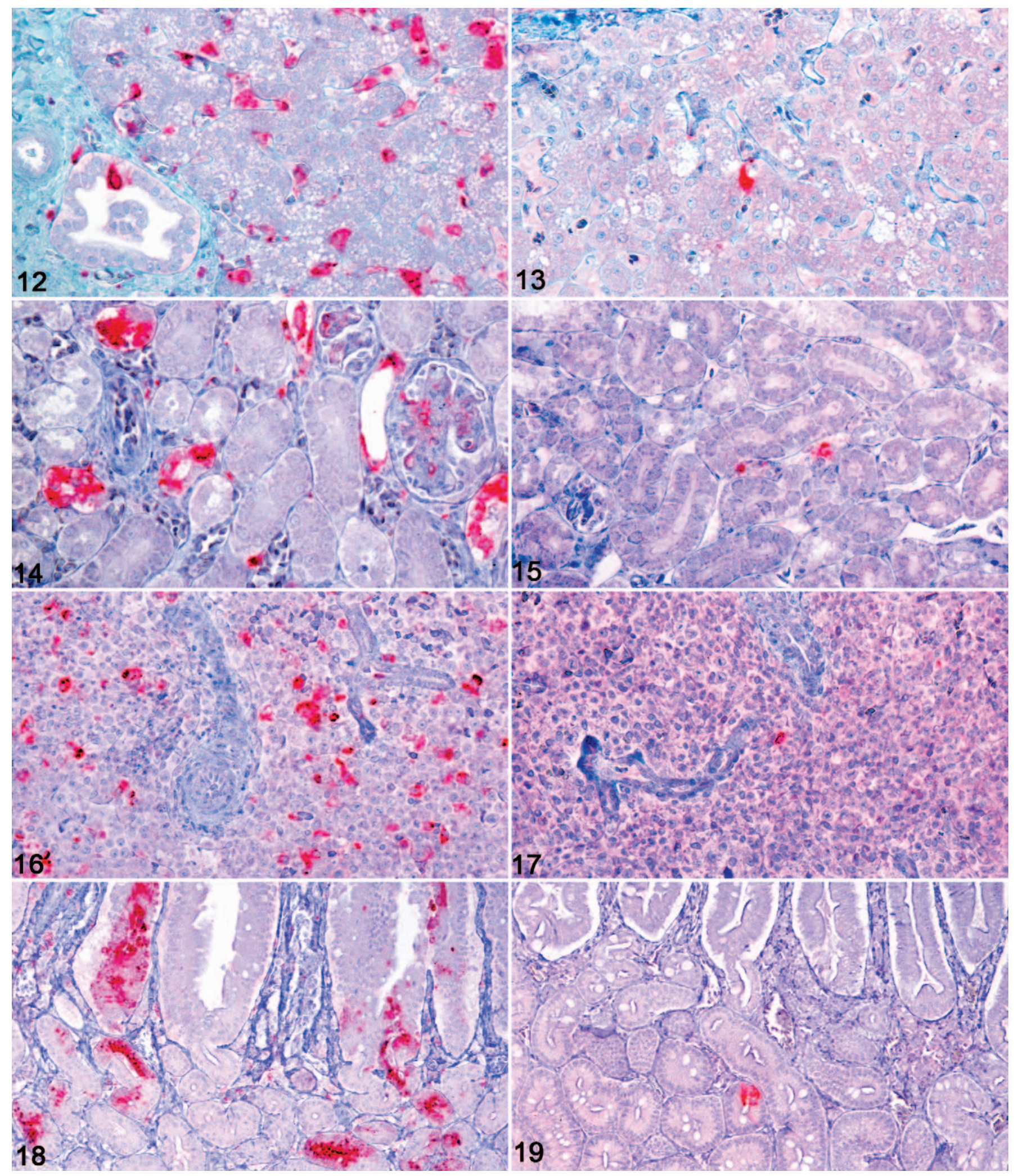

Figure 12. Liver; American crow No. 2. Abundant West Nile virus (WNV) antigen is within Kupffer cells and monocytes, along with rare staining of the biliary epithelium. Immunohistochemistry for WNV with hematoxylin counterstain. Figure 13. Liver; fish crow No. 6. An individual Kupffer cell contains WNV antigen. Immunohistochemistry for WNV with hematoxylin counterstain. Figure I4. Kidney; American crow No. I. WNV antigen is relatively abundant in renal tubular epithelium, interstitium, and glomeruli. Immunohistochemistry for WNV with hematoxylin counterstain. Figure I5. Kidney; fish crow No. 5. Minimal amounts of WNV antigen are in the kidney, with only rare 
smooth muscle and in neurons within myenteric ganglia. The cecum and proximal large intestine had a similar antigenstaining pattern as the small intestine; however, tissues were not available for all crows. The granulomatous coelomitis observed on the serosal surface of the small intestine of crow No. 2 contained large numbers of macrophages filled with viral antigen. In contrast to American crows, minimal WNV antigen was detected in the gastrointestinal tract of fish crows (Fig. 19). In fish crows, antigen was most prominent in the mononuclear phagocytic cells of gut-associated lymphoid tissue and infrequently in monocytes, interstitial macrophages within the lamina propria, mucosal epithelial cells, and ganglia. Antigen staining in the pancreas of both crow species followed a similar pattern as in the intestinal tract. Among American crows, there were multifocal areas of intact and necrotic pancreatic acinar cells containing WNV antigen, with lesser amounts of antigen in monocytes and endothelial cells. In contrast, fish crows had little or no antigen within the pancreas, which was limited to acinar cells.

In myocardium of American crows, WNV antigen was primarily within intact and degenerate myofibers, with lesser amounts of antigen in interstitial cells, monocytes, endothelial cells, and cells lining the endocardium and epicardium. There were similar but lesser amounts of antigen in fish crow hearts. In lungs of American crows, WNV antigen was primarily within monocytes and macrophages, with minimal staining of bronchiolar epithelium and endothelial cells. Lesser amounts of antigen were present in a similar pattern in fish crows, in which antigen was most concentrated in mononuclear phagocytic cells of the bronchus-associated lymphoid tissue.

WNV antigen was limited or absent from brain and spinal cord of both crow species. Within brain of American crows, staining was primarily within the meninges, endothelial cells, monocytes, and macrophages, with rare staining of ependymal cells. Within the gray matter of the brain, WNV antigen was primarily in the brain stem and cerebellum, including rare individual and small clusters of neurons, glial cells, and cerebellar Purkinje cells. Similarly, the majority of antigen in the spinal cord was within the meninges and gray matter. In fish crows, only crow No. 6 had significant staining in the brain and spinal cord, limited to monocytes, macrophages, and meningeal endothelial cells. Within the eye, antigen was rare in monocytes or macrophages within the ciliary body of 2 of 3 American crows (Nos. 1 and 3; see Supplemental Table 4). No WNV antigen was identified in eyes of fish crows.

\section{Discussion}

The underlying reasons for the varied susceptibility among North American bird species to WNV-induced morbidity and mortality are not well understood. Potential contributing factors include host traits such as genetic composition, immune response, and physiologic response mechanisms. As a group, corvids (eg, ravens, crows, and jays) are vulnerable to WNV-associated mortality, the rates of which vary by species and can be as high as $100 \% .{ }^{4,17,28}$ In areas of WNV transmission, negative population trends for American crows have been documented, and regional populations of American crows and other corvid species have been slow to recover. ${ }^{7,9,16,19}$

WNV pathogenesis in birds often entails early onset of viremia, followed by rapid viral invasion of all organ systems. ${ }^{17,21,22}$ In the present study, WNV gained access to all 15 tissues tested in both crow species, but replication patterns varied by species. WNV replication was apparently uncontrolled in blood and other tissues of American crows at the time of severe morbidity and death (ie, 6 DPI), concurrent with suppressed levels of circulating antibodies. Peak viremia titers in American crows were approximately 3,000 times higher and occurred 1 to 2 days later than in fish crows. Tissue titers measured on 6 DPI were up to 49,000 times higher in American versus fish crows. Immunohistochemistry antigen levels generally corresponded with infectious viral titers, being highest in gastrointestinal tract and associated parenchymal tissues (eg, liver and pancreas) as well as spleen.

Hematologic and biochemistry profiles corresponding to WNV clinical disease in birds have included heterophilic leukocytosis and anemia, with occasional monocytosis and reactive lymphocytes. ${ }^{10,15}$ Similarly, crows in the present study had mild to moderate transient leukocytosis with heterophilia, as well as decreased levels of glucose, hemoglobin, and hematocrit. Serial blood collections may have contributed to the latter. In American crows, uncompensated metabolic acidemia ( 2 of 3 ) and respiratory alkalemia ( 1 of 3 ) was observed; concurrent bacterial pneumonia and possible effects of handling stress (eg, hyperventilation) in the latter crow may have contributed to the respiratory alkalemia. Dehydration and acid-base imbalances in American crows may have resulted from disproportionate loss or retention of electrolytes (eg, bicarbonate, sodium, potassium, chlorine) from the intestines and kidneys. WNV-induced damage to the intestinal epithelium is consistent with the clinical observations of severe diarrhea. Cellular injury and decreased function of the digestive and urinary systems are further supported by histologic lesions and abundant WNV antigen in the proventriculus, intestine, and kidney. Increased heart rates in American crows at 6 DPI likely reflected sympathetic stimulation secondary to significant systemic illness and dehydration. In contrast to these clinical and pathologic changes in American crows, serum biochemistry and clinical status of fish crows remained similar

Figure 15. (continued) monocytes containing WNV antigen. Immunohistochemistry for WNV with hematoxylin counterstain. Figure 16. Spleen; American crow No. 2. Abundant WNV antigen is within both the red pulp and the white pulp. Immunohistochemistry for WNV with hematoxylin counterstain. Figure 17. Spleen; fish crow No. 5. Very small amounts of WNV antigen are in both red pulp and white pulp. Immunohistochemistry for WNV with hematoxylin counterstain. Figure I 8. Small intestine; American crow No. 2. Large amounts of WNV antigen is within the crypt and villous epithelium. Immunohistochemistry for WNV with hematoxylin counterstain. Figure I9. Small intestine; fish crow No. 4. Limited amounts of WNV antigen is within the crypt epithelium. Immunohistochemistry for WNV with hematoxylin counterstain. 
before and after WNV infection. Data interpretation is limited by small groups of wild-caught (ie, heterogeneous) birds.

Gross lesions documented in WNV-infected birds are often nonspecific and inconsistent. Gross observations in present and past studies included splenomegaly and cerebral congestion. ${ }^{13,27}$ Splenomegaly was observed in the present study in both American and fish crows, whereas cerebral congestion was limited to American crows. Additional gross observations in American crows were consistent with histopathology, including dilated and discolored intestines, enlarged and darkened or mottled kidneys and pancreas, and intracoelomic fluid (which may have resulted from vascular damage). Individuals of both crow species were euthanized at the same time point (6 DPI), at which time all American crows exhibited signs of severe illness. Although fish crows appeared healthy at this time point, further progression and final outcome of WNV infection in these individuals are unknown.

Microscopic lesion and WNV antigen distribution patterns were qualitatively similar in American and fish crows, but tissues of American crows had more severe lesions and greater amounts of viral antigen. In American crows, WNV antigen was frequently identified in monocytes, macrophages, and other reticuloendothelial cells, consistent with previous studies in birds. ${ }^{12,27,29}$ In vitro studies involving mice and humans have demonstrated that WNV infection suppresses macrophage function by inhibiting the production of proinflammatory and antiviral cytokines. ${ }^{2,18}$ American crows had moderate to severe splenic lymphoid necrosis, and there was abundant WNV antigen in both the red pulp and the white. The areas of mild to moderate necrosis in the pancreas consistently contained abundant viral antigen. American crows also had early myocardial degeneration, and viral antigen was present in degenerate myocytes and associated inflammatory aggregates. Limited myocardial inflammation in both crow species was consistent with the normal ECG readings. Multiple organs (ie, kidney, pancreas, intestine, proventriculus, ventriculus, and cecum) had vasculitis with WNV antigen within endothelial cells and, less frequently, ganglioneuritis with viral antigen in neurons. In contrast to American crows, fish crows had less frequent and less severe inflammation and necrosis and lesser amounts of viral antigen in tissues such as heart, pancreas, liver, spleen, intestine, and cecum.

Histopathologic examination of experimentally and naturally infected noncorvid birds has most commonly included inflammation in multiple organs (eg, myocarditis, encephalitis, endophthalmitis, and pancreatitis) with occasional vasculitis, whereas in corvids, necrosis of spleen, liver, and bone marrow has been documented. 1,13,21,22,25,27,29,31-33 Encephalitis has been observed in a variety of birds naturally infected with WNV, including American crows. ${ }^{1,27}$ Notably in the present study, encephalitis was absent in both crow species, and there was minimal WNV antigen deposition in tissues of the central nervous system. This is consistent with past studies of experimentally and naturally infected American crows in which WNV antigen (by immunohistochemistry) was rare in brain, and encephalitis was absent. ${ }^{29,33}$ Mild to moderate rhabdomyolysis in all crows was attributable to capture myopathy, which has been described in birds. ${ }^{26}$

Following examination of zoo and free-ranging birds representing 8 taxonomic orders naturally infected with WNV, Steele and coauthors ${ }^{27}$ concluded that extensive lesions in a variety of tissues (eg, heart, pancreas, kidney, adrenal gland, and liver) may have led to altered physiologic status resulting in recumbency and generalized weakness, thereby suggesting neural and extraneural involvement in fatal clinical disease. Blue jays (Cyanocitta cristata) inoculated with WNV were unable to perch and fly, which, with lack of WNV antigen and lesions in the brain, was hypothesized to be due to generalized infection and skeletal muscle weakness rather than central nervous system involvement. ${ }^{29}$ In the present study, clinical WNV disease in American crows (eg, lethargy, muscle weakness, and dehydration) may have been nonneurologic in origin but rather occurred as a sequela to electrolyte (including hypocalcemia) and $\mathrm{pH}$ alterations, renal tubular degeneration, and intestinal necrosis and inflammation. The lack of lesions and WNV antigen in brains and spinal cords of American crows further supports that the observed morbidity and mortality resulted from multisystemic disease and not primary neurologic disease, as is the case in horses and some other WNV-infected mammals. ${ }^{814}$ Decreased alertness and neurologic responses in American crows late in the time course of infection may be a result of the burden and effects of systemic infection. Crows in the present study had concurrent bacterial and fungal infections, a finding that has been documented among birds naturally infected with WNV. ${ }^{25,27,33}$ The role of underlying secondary infections in the outcome of WNV infection in crows and other birds is unknown. Crows and other birds may experience increased pathogen exposure and subsequent immunosuppression based on behaviors such as scavenging, predation, and frequent intraspecific and interspecific social interactions.

In conclusion, we evaluated the clinical, physiologic, and humoral immune responses to WNV infection that corresponded to patterns of viral pathogenesis in congeneric crow species. Clinical, serum biochemistry, virology, serology, and pathology data suggest that the rapid decline in American crows, as opposed to fish crows, was due to a cascade of events, including marked and widespread viral replication and delayed or depressed humoral immune responses, leading to cellular injury within the kidney, intestine, and other tissues and thus contributing to multiorgan malfunction with severe weakness and lethargy. Secondary infections may be more common in corvids than other avian species and could thus contribute to their rapid demise in the face of WNV infection. Although there is no specific treatment to combat WNV infection in birds, supportive strategies should include corrective fluid and nutrition therapies to remedy acid-base and electrolyte imbalances and dehydration, as well as judicious use of antibiotic and antimycotic drugs to combat secondary infections.

\section{Acknowledegment}

We are grateful to Christi Yoder for supplying crows; Gordon Gathright and the National Wildlife Research Center Animal Care 
Staff for providing animal care before the study; and Ginger Young, Julie Lease, and James Fosse for their excellent technical assistance. We thank the reviewers and editors for their efforts toward improving the article.

\section{Declaration of Conflicting Interests}

The authors declared that they had no conflicts of interest with respect to their authorship or the publication of this article.

\section{Financial Disclosure/Funding}

This work was supported in part by National Institutes of Health contract No. N01-AI25489.

\section{References}

1. Anderson JF, Andreadis TG, Vossbrinck CR, Tirrell S, Wakem EM, French RA, Garmendia AE, Van Kruiningen HJ: Isolation of West Nile virus from mosquitoes, crows, and a Cooper's hawk in Connecticut. Science 286:2331-2333, 1999.

2. Arjona A, Ledizet M, Anthony K, Bonafé N, Modis Y, Town T, Fikrig E: West Nile virus envelope protein inhibits dsRNAinduced innate immune responses. J Immunol 179:8403-8409, 2007.

3. Beaty BJ, Calisher CH, Shope, RE: Arboviruses. In: Diagnostic Procedures for Viral, Rickettsial, and Chlamydial Infections, ed. Lennette EH, Lennette DA, and Lennette ET, 7th ed., pp. 189212. American Public Health Association, Washington, DC, 1995.

4. Brault AC, Langevin SA, Bowen RA, Panella NA, Biggerstaff BJ, Miller BJ, Komar N: Differential virulence of West Nile strains for American crows. Emerg Infect Dis 10:2161-2168, 2004.

5. Bunning ML, Bowen RA, Cropp CB, Sullivan KG, Davis BS, Komar N, Godsey MS, Baker D, Hettler DL, Holmes DA, Biggerstaff BJ, Mitchell CJ: Experimental infection of horses with West Nile virus. Emerg Infect Dis 8:380-386, 2002.

6. Burnham KP, Anderson DR: Model Selection and Multimodel Inference: A Practical Information-Theoretic Approach, 2nd ed., pp. 35-37. Springer-Verlag, New York, NY, 2002.

7. Caffrey C, Smith SCR, Weston TJ: West Nile virus devastates an American crow population. Condor 107:128-132, 2005.

8. Cantile C, Del Piero F, DiGuardo G, Arispici M: Pathologic and immunohistochemical findings in naturally occurring West Nile virus infection in horses. Vet Pathol 38:414-421, 2001.

9. Crosbie SP, Koenig WD, Reisen WK, Kramer VL, Marcus L, Carney R, Pandolfino E, Bolen GM, Crosbie LR, Bell DA, Ernest HB: Early impacts of West Nile virus on the yellow-billed magpie (Pica nuttalli). Auk 125:542-550, 2008.

10. D'Agostino JJ, Isaza R: Clinical signs and results of specific diagnostic testing among captive birds housed at zoological institutions and infected with West Nile virus. J Am Vet Med Assoc 224:1640-1643, 2004.

11. Eidson M, Komar N, Sorhage F, Nelson R, Talbot T, Mostashari F, McLean R: West Nile virus avian mortality surveillance group: crow deaths as a sentinel surveillance system for West Nile virus in the northeastern United States, 1999. Emerg Infect Dis 7:615$620,2001$.
12. Ellis AE, Mead DG, Allison AB, Gibbs SEJ, Gottdenker NL, Stallknecht DE, Howerth EW: Comparison of immunohistochemistry and virus isolation for diagnosis of West Nile virus. J Clin Microbiol 43:2904-2908, 2005.

13. Ellis AE, Mead DG, Allison AB, Stallknecht DE, Howerth EW: Pathology and epidemiology of natural West Nile viral infection of raptors in Georgia. J Wildl Dis 43:214-223, 2007.

14. Heinz-Taheny KM, Andrews JJ, Kinsel MJ, Pessier AP, Pinkerton ME, Lemberger KY, Novak RJ, Dizikes GJ, Edwards E, Komar $\mathrm{N}$ : West Nile virus infection in free-ranging squirrels in Illinois. J Vet Diagn Invest 16:186-190, 2004.

15. Joyner PH, Kelly S, Shreve AA, Snead SE, Sleeman JM, Pettit DA: West Nile virus in raptors from Virginia during 2003: clinical, diagnostic, and epidemiologic findings. J Wildl Dis 42:335344, 2006.

16. Koenig WD, Marcus L, Scott TW, Dickinson JL: West Nile virus and California breeding bird declines. Ecohealth 4:18-24, 2007.

17. Komar N, Langevin S, Hinten S, Nemeth N, Edwards E, Hettler D, Davis B, Bowen R, Bunning M: Reservoir competence of North American birds for the New York 1999 strain of West Nile virus. Emerg Infect Dis 9:311-322, 2003.

18. Kong KF, Wang X, Anderson JF, Fikrig E, Montgomery RR. West Nile virus attenuates activation of primary human macrophages. Viral Immunol 21:78-82, 2008.

19. LaDeau SL, Kilpatrick AM, Marra PP: West Nile virus emergence and large-scale declines of North American bird populations. Nature 447:710-713, 2007.

20. Nemeth N, Bowen R: Dynamics of passive immunity to West Nile virus in domestic chickens (Gallus gallus domesticus). Am J Trop Med Hyg 76:310-317, 2007.

21. Nemeth N, Gould D, Bowen R, Komar N: Natural and experimental West Nile virus infection in five raptor species. J Wildl Dis 42:1-13, 2006.

22. Nemeth N, Hahn C, Gould D, Bowen R: Experimental West Nile virus infection in Eastern screech owls (Megascops asio). Avian Dis 50:252-258, 2006.

23. Nemeth NM, Oesterle PT, Bowen RA: Humoral immunity to West Nile virus is long-lasting and protective in the house sparrow (Passer domesticus). Am J Trop Med Hyg 80:864-869, 2009.

24. Reed LM, Johansson MA, Panella N, McLean R, Creekmore T, Puelle R, Komar N: Declining mortality in American crow (Corvus brachyrhynchos) following natural West Nile virus infection. Avian Dis 53:458-461, 2009.

25. Saito EK, Sileo L, Green E, Meteyer CU, McLaughlin GS, Converse KA, Docherty DE: Raptor mortality due to West Nile virus in the United States, 2002. J Wildl Dis 43:206-213, 2007.

26. Spraker TR, Adrian WJ, Lance WR: Capture myopathy in wild turkeys (Meleagris gallopavo) following trapping, handling and transportation in Colorado. J Wildl Dis 23:447-453, 1987.

27. Steele KE, Linn MJ, Schoepp RJ, Komar N, Geisbert TW, Manduca RM, Calle PP, Raphael BL, Clippinger TL, Larsen T, Smith J, Lanciotti RS, Panella NA, McNamara TS: Pathology of fatal West Nile virus infections in native and exotic birds during the 1999 outbreak in New York City, New York. Vet Pathol 37:208-224, 2000.

28. Turell MJ, Bunning M, Ludwig GV, Ortman B, Chang J, Speaker T, Spielman A, McLean R, Komar N, Gates R, McNamara T, 
Creekmore T, Farley L, Mitchell CJ: DNA vaccine for West Nile virus infection in fish crows (Corvus ossifragus). Emerg Infect Dis 9:1077-1081, 2003.

29. Weingartl HM, Neufeld JL, Copps J, Marszal P: Experimental West Nile virus infection in blue jays (Cyanocitta cristata) and crows (Corvus brachyrhynchos). Vet Pathol 41:362-370, 2004.

30. Wilcox BR, Yabsley MJ, Ellis AE, Stallknecht DE, Gibbs SEJ: West Nile virus antibody prevalence in American crows (Corvus brachyrhynchos) and fish crows (Corvus ossifragus) in Georgia, USA. Avian Dis 51:125-128, 2007.

31. Wünschmann A, Shivers J, Bender J, Carroll L, Fuller S, Saggese M, van Wettere A, Redig P: Pathologic findings in red-tailed hawks (Buteo jamaicensis) and Cooper's hawks (Accipiter cooperi) naturally infected with West Nile virus. Avian Dis 48:570-580, 2004.

32. Wünschmann A, Shivers J, Bender J, Carroll L, Fuller S, Saggese M, van Wettere A, Redig P: Pathologic and immunohistochemical findings in goshawks (Accipiter gentilis) and great horned owls (Bubo virginianus) naturally infected with West Nile virus. Avian Dis 49:252-259, 2005.

33. Wünschmann A, Shivers J, Carroll L, Bender J: Pathological and immunohistochemical findings in American crows (Corvus brachyrhynchos) naturally infected with West Nile virus. J Vet Diagn Invest 16:329-333, 2004. 